\title{
Langerhans cells are critical in epicutaneous sensitization with protein antigen via thymic stromal lymphopoietin receptor signaling.
}

\section{$\operatorname{AUTHOR}(S)$ :}

Nakajima, Saeko; Igyártó, Botond Z; Honda, Tetsuya; Egawa, Gyohei; Otsuka, Atsushi; Hara-Chikuma, Mariko; Watanabe, Norihiko; ... Miyachi, Yoshiki; Kaplan, Daniel H; Kabashima, Kenji

\section{CITATION:}

Nakajima, Saeko ...[et al]. Langerhans cells are critical in epicutaneous sensitization with protein antigen via thymic stromal lymphopoietin receptor signaling.. The Journal of allergy and clinical immunology 2012, 129(4): 1048-1055.e6

\section{ISSUE DATE:}

2012-04

URL:

http://hdl.handle.net/2433/155085

\section{RIGHT:}

(C) 2012 American Academy of Allergy, Asthma \& Immunology.

Published by Mosby, Inc.; This is not the published version. Please cite only the published version.; この論文は出版社版でありません。引用の 際には出版社版をご確認ご利用ください。 
1 Langerhans cells are critical in epicutaneous sensitization with protein antigen via

\section{$2 \quad$ TSLP receptor signaling}

3

4 Saeko Nakajima ${ }^{1}$, MD, Botond Igyarto ${ }^{2}, \mathrm{PhD}$, Tetsuya Honda ${ }^{1}$, MD, PhD, Gyohei

5 Egawa $^{1}, \mathrm{MD}, \mathrm{PhD}$, Atsushi Otsuka ${ }^{1}, \mathrm{MD}, \mathrm{PhD}$, Mariko Hara-Chikuma ${ }^{1,3}, \mathrm{PhD}$,

6 Norihiko Watanabe ${ }^{3}, \mathrm{MD}, \mathrm{PhD}$, Steven F Ziegler ${ }^{4}, \mathrm{PhD}$, Michio Tomura ${ }^{3}, \mathrm{PhD}$, Kayo

$7 \quad$ Inaba $^{5}, \mathrm{PhD}$, Yoshiki Miyachi ${ }^{1}, \mathrm{MD}, \mathrm{PhD}$, Daniel H Kaplan ${ }^{2}, \mathrm{MD}, \mathrm{PhD}$, and Kenji

8 Kabashima $^{1}, \mathrm{MD}, \mathrm{PhD}$

9

$10{ }^{1}$ Department of Dermatology and ${ }^{3}$ Center for Innovation in Immunoregulative

11 Technology and Therapeutics, Kyoto University Graduate School of Medicine

$12{ }^{2}$ Department of Dermatology, Center for Immunology, University of Minnesota

$13{ }^{4}$ Immunology Program, Benaroya Research Institute, Seattle, Washington 98101, USA

$14{ }^{5}$ Department of Animal Development and Physiology, Kyoto University Graduate

15 School of Biostudies, Kyoto, Japan

16 Address correspondence and reprint requests to: Dr. Kenji Kabashima

17 Department of Dermatology, Kyoto University Graduate School of Medicine

1854 Shogoin Kawara, Sakyo, Kyoto 606-8507, Japan

19 Tel: +81-75-751-3310, Fax: +81-75-761-3002

20 Email address: kaba@kuhp.kyoto-u.ac.jp

21

\section{Declaration of all sources of funding}

23 This work was supported in part by Grants-in-Aid for Scientific Research from the

24 Ministries of Education, Culture, Sports, Science and Technology (K.K.), and by a 
25 Grant-in-Aid from the Japan Society for the Promotion of Science Fellows (N.S.). The

26 authors have no conflicting interests.

27

28

29 Total word count: 3140 words

30

31

32

33

34

35

36

37

38

39

40

41 


\section{Abstract}

43 Background: Clarification of cutaneous dendritic cell (DC) subset and the role of

44 thymic stromal lymphopoietin (TSLP) signaling in epicutaneous sensitization with 45 protein antigens, as in the development of atopic dermatitis (AD), is a crucial issue.

46 Objectives: Since TSLP is highly expressed in the vicinity of Langerhans cells (LCs), 47 we sought to clarify our hypothesis that LCs play an essential role in epicutaneous sensitization with protein antigens through TSLP signaling.

49 Methods: Using Langerin-diphtheria toxin receptor knockin mice and human 50 Langerin-diphtheria toxin A transgenic mice, we prepared mice deficient in LC. We also prepared mice deficient in TSLP receptor in LCs using TSLP receptor deficient mice with bone marrow chimeric technique. We applied these mice to an ovalbumin-induced epicutaneous sensitization model.

54 Results: Upon the epicutaneous application of OVA, conditional LC-depletion attenuated the development of clinical manifestations as well as serum OVA-specific IgE increase, OVA-specific T cell proliferation, and IL-4 mRNA expression in the draining lymph nodes. Consistently, even in the steady state, permanent LC depletion resulted in decreased serum IgE levels, suggesting that LCs mediate Th2 local

59 environment. In addition, mice deficient in TSLP receptor on LCs abrogated the 60 induction of OVA-specific IgE levels upon epicutaneous OVA sensitization.

61 Conclusion: LCs initiate epicutaneous sensitization with protein antigens and induce 62 Th2-type immune responses via TSLP signaling.

\section{Clinical implications}

65 TSLP receptors on LCs can be a therapeutic target of skin inflammatory reactions 
66 induced by epicutaneous sensitization with protein antigens, such as in the development

67 of atopic dermatitis.

68

69 Capsule summary

70 LCs initiate epicutaneous sensitization with protein antigens and induce Th2-type

71 immune responses via TSLP-TSLP receptor signaling.

72

73 Key words: Langerhans cell, TSLP, TSLP receptor, epicutaneous sensitization, protein 74 antigen

75

$76 \quad$ Abbreviations used

$77 \quad \mathrm{AD}$, atopic dermatitis

$78 \mathrm{BM}$, bone marrow

79 BMC, bone marrow chimera

80 CCR, CC chemokine receptor

81 DCs, dendritic cells

82 DTA, diphtheria toxin subunit A

83 DTR, diphtheria toxin receptor

84 EGFP, enhanced green fluorescent protein

85 LCs, Langerhans cells

86 LN, lymph node

87 MDC, macrophage-derived chemokine

88 MFI, mean fluorescence intensity

89 OVA, ovalbumin 
90 TARC, thymus and activation-regulated chemokine

91 TSLP, thymic stromal lymphopoietin

92 TSLPR, TSLP receptor

93 TJ, tight junction

94

95

96

97

98

99

100

101

102

103

104

105

106

107

108

109

110

111

112

113

114

115

116

117

118

119

120

121

122 


\section{INTRODUCTION}

124 Skin plays an important immunological role by eliciting a wide variety of immune

125 responses to foreign antigens (1). Atopic dermatitis (AD) is a pruritic chronic retractable

126 inflammatory skin disease that is induced by the complex interaction between

127 susceptibility genes encoding skin barrier components and stimulation by protein

128 antigens $(2,3)$. Patients with $\mathrm{AD}$ exhibit compromised barrier function that leads to the

129 activation of keratinocytes and immune cells, which favors a Th2 bias. A wide array of

130 cytokines and chemokines interact to yield symptoms that are characteristic of AD. For

131 example, thymus and activation-regulated chemokine (TARC/CCL17) and

132 macrophage-derived chemokine (MDC/CCL22) both attract Th2 cells through CC

133 chemokine receptor 4 (CCR4) (4), levels of which correlate well with the severity of

$134 \mathrm{AD}$ (5). Elevation of serum IgE levels is also frequently found in patients with $\mathrm{AD}$,

135 sometimes concomitant with food allergy, allergic rhinitis, and asthma (3). Yet it

136 remains unknown how elevation of serum $\operatorname{IgE}$ levels to protein antigens is induced in

137 the pathogenesis of AD.

138 Upon protein antigen exposure, dendritic cells (DCs) acquire antigens and stimulate

139 the proliferation of $\mathrm{T}$ cells to induce distinct $\mathrm{T}$ helper cell responses to external

140 pathogens (6). Therefore, it has been suggested that DCs initiate AD in humans (7),

141 however, it remains unclarified which cutaneous DC subset initiates epicutaneous

142 sensitization to protein antigens. In the mouse skin, there are at least three subsets of

143 DCs: LCs in the epidermis, and Langerin-positive and Langerin-negative DCs in the

144 dermis (Langerin ${ }^{+}$dermal DCs and Langerin ${ }^{-}$dermal DCs, respectively) (8-10). It has

145 been reported that application of large molecules are localized above the size-selective

146 barrier, tight junction (TJ), and that activated LCs extend their dendrites through the TJ 
147 to take up antigens (11). Therefore, it can be hypothesized that not dermal DCs but

148 rather LCs initiate epicutaneous sensitization with protein antigens, as in the

149 development of AD.

150 In human, polymorphisms in the gene encoding the cytokine thymic stromal

151 lymphopoietin (TSLP) are associated with the development of multiple allergic

152 disorders through TSLP receptor (TSLPR), which is expressed in several cell types,

153 such as DCs, T cells, B cells, basophils, and eosinophils $(12,13)$. Thus, TSLP seems to

154 be a critical regulator of Th2 cytokine-associated inflammatory diseases.

155 Recently, it has been reported that basophils induce Th2 through TSLPR (13). On the

156 other hand, it is also known that skin DCs elicit a Th2 response in the presence of

157 mechanical injury by inducing cutaneous TSLP (14), and that LCs are critical in the

158 development of skin lesions induced by the topical application of vitamin D3 analogues

159 through TSLP signaling (15). However, these skin inflammation models are induced in

160 an antigen-independent manner; therefore, it is important to address the degree to how

161 TSLP is essential in Th2 shifting and to identify the cells that are essential for TSLP

162 signaling transduction upon epicutaneous sensitization, which is relevant to

163 inflammatory skin diseases, such as AD. This will lead to the understanding of the

164 underlying mechanism and to develop new therapeutic targets for inflammatory skin

165 diseases.

166 It is known that TSLP activates human epidermal LCs and DCs in vitro (16-18) and

167 that TSLP is highly expressed in the epidermis of the lesional skin of AD patients. Since

168 LCs are localized in the epidermis, we hypothesized that LCs initiate epicutaneous

169 sensitization through TSLP signaling. By applying an LC ablation system, we found

170 that LCs are crucial for Th2 induction and IgE production upon epicutaneous protein 
exposure through TSLP signaling.

172

\section{MATERIALS AND METHODS}

\section{Animals and bone marrow chimera}

175 C57BL6 (B6) and BALB/c mice were purchased from Japan SLC (Shizuoka, Japan).

176 OT-II TCR transgenic mice were purchased from the Jackson Laboratory (Bar Harbor,

177 ME, USA). Langerin-DTA mice were generated by Dr. Daniel Kaplan (19), and

178 Langerin-eGFP-DTR knock-in mice were kindly provided by Dr. Bernard Mallissen

179 (CIML, Institut National de la Santé et de la Recherche Médicale, Marseille, France).

$180 \mathrm{TSLPR}^{-/-}$mice (BALB/c or B6 background) were generated by Dr. Steven Ziegler

181 (20). Seven- to twelve-week-old female mice bred in specific pathogen-free facilities at 182 Kyoto University were used for all experiments.

183 For LC depletion specifically, Langerin-eGFP-DTR mice were used. Intraperitoneal 184 injection of $1 \mu \mathrm{g}$ DT (Sigma-Aldrich, St. Louis, MO, USA, in $500 \mu 1$ of PBS) depleted 185 Langerin $^{+}$DC subsets, including LCs and Langerin ${ }^{+}$dermal DCs. Langerin ${ }^{+}$dermal DCs 186 in the dermis recover one week after DT injection, but LCs remain undetectable for four 187 weeks after depletion (21). Since only LCs are depleted between one and three weeks 188 after DT injection, we can evaluate the role of LCs in epicutaneous sensitization by 189 applying OVA between one and three weeks after DT injection. Therefore, we injected 190 DT seven days before epicutaneous sensitization. Control mice were intraperitoneally 191 injected with $500 \mu 1$ of PBS on the same day.

192 To generate bone marrow chimeric mice, 6-week-old mice were irradiated (9 Gy) and 193 transplanted with bone marrow cells $\left(1 \times 10^{7}\right.$ cells/recipient $)$. All experimental 
194 procedures were approved by the institutional animal care and use committee of Kyoto University Graduate School of Medicine.

196

\section{Epicutaneous sensitization}

198 Mice were anesthetized with diethylethel (Nacalai Tesque, Kyoto, Japan), and then

199 shaved with an electric razor (THRIVE Co. Ltd., Osaka, Japan). A single skin site on

200 each mouse was tape-stripped at least five times with adhesive cellophane tape

201 (Nichiban, Tokyo, Japan). One hundred $\mu \mathrm{g}$ of OVA in $100 \mu 1$ of normal saline or 202 placebo (100 $\mu 1$ of normal saline) was placed on patch-test tape (Torii Pharmaceutical

203 Co., Ltd., Tokyo, Japan). Each mouse had a total of three two-day exposures to the 204 patch, separated by one-day intervals. Mice were euthanized at the end of the third cycle 205 of sensitization (day 9).

206

207 Antigen-specific T cell proliferation

208 To assess the OVA-specific T cell priming capacity of cutaneous LCs, $100 \mu 1$ of normal 209 saline with or without $100 \mu \mathrm{g}$ of OVA was placed on the shaved and tape-stripped 210 mouse back skin. CD4 T cells were isolated from OT-II mice using magnetic bead 211 separation (Miltenyi Biotec, Bergisch Gladbach, Germany) and labeled with $8 \mu \mathrm{M}$

212 CFSE. Forty-eight hours after epicutaneous sensitization, 5 x $10^{6}$ CFSE labeled OT-II T 213 cells were transferred to naïve mice via the tail vein. An additional 48 hours later, skin 214 draining brachial lymph nodes (LNs) were collected and analyzed by means of flow 215 cytometry.

\section{Statistical analysis}


218 Unless otherwise indicated, data are presented as means \pm standard deviations (SD), and

219 each data point is representative of three independent experiments. $P$ values were

220 calculated according to the two-tailed Student's t-test.

221

222 A complete description of the materials and methods, and any associated references are 223 available in the Online Repository.

\section{$225 \quad$ RESULTS}

226 LC depletion impaired the development of OVA-induced allergic skin dermatitis 227 model

228 To assess the role of LCs in epicutaneous sensitization with protein antigens and 229 induction of IgE, we applied OVA to mice epicutaneously (22). In this model, we 230 observed a rise in OVA-specific serum IgE and $\mathrm{IgG1}$, both of which are induced in a 231 Th2-dependent manner, as well as the development of dermatitis characterized by the 232 infiltration of $\mathrm{CD}^{+} \mathrm{T}$ cells, eosinophils, and neutrophils and local expression of mRNA 233 for the cytokines interleukin (IL)-4, IL-5, and interferon (IFN)- $\gamma(22)$. These findings 234 exhibited characteristics of allergic skin inflammation such as AD. To evaluate the roles 235 of LCs, we used knock-in mice expressing enhanced green fluorescent protein (EGFP) 236 and diphtheria toxin receptor (DTR) under the control of the Langerin gene, called 237 Langerin-eGFP-DTR mice (23).

238 In the OVA-induced allergic skin dermatitis model, LC-depleted mice showed milder 239 clinical manifestations than LC-non-depleted mice did (Fig. 1A, left panel). Histology 240 of the patched skin area showed pronounced lymphocyte infiltration and edema in the 241 dermis of sensitized LC-non-depleted mice, which was less apparent in sensitized 
LC-depleted mice (Fig. S1A, B). The histological score of LC-depleted mice was also lower than that of LC-non-depleted mice (Fig. 1A, right panel). In addition, serum

244 OVA-specific IgE and IgG1 levels in LC-depleted mice were significantly lower than

245 those in wild-type (WT) mice (Fig. 1B). On the other hand, the Th1-dependent

246 immunoglobulin IgG2a was not induced by application of OVA (Fig. 1B). These data

247 suggest that LCs are involved in the development of OVA-induced AD-like skin

248 inflammation and induction of IgE.

\section{Impaired $T$ cell proliferation and Th2 induction by $\mathrm{LC}$ depletion}

251 Priming of antigen-specific Th2 cells and proliferation is an important step in the development of this model. To assess the T cell priming capacity of cutaneous LCs upon protein allergen exposure, LC-depleted and non-depleted mice were sensitized with OVA percutaneously on the back and transferred with carboxyfluorescein succinimidyl ester (CFSE)-labeled OT-II T cells which express an OVA-specific T cell antigen receptor. Next, single-cell suspensions prepared from the skin-draining brachial

257 lymph nodes (LNs) were analyzed by means of flow cytometry to evaluate T cell

258 division by LCs in the draining LNs. LC-depleted mice showed impaired T cell division 259 after OVA sensitization compared with LC non-depleted mice, suggesting that LCs 260 stimulate T cell proliferation, at least to some degree, in this model (Fig. 2A and B).

261 To evaluate the role of LCs in T cell priming, we examined the mRNA expression of 262 Th2 cytokine IL-4 and Th1 cytokine IFN- $\gamma$ in draining LNs after OVA sensitization.

263 The IL-4 mRNA expression level of draining LNs was significantly decreased in 264 LC-depleted mice, while the IFN- $\gamma$ mRNA expression level was significantly higher in 265 LC-depleted mice than in LC-non-depleted mice (Fig. 2C). These results suggest that 
266 LCs are crucial for stimulating T cell proliferation to a certain extent and Th2 induction 267 pronouncedly in skin-draining LNs in this model.

268

269 LCs are responsible for initiating epicutaneous sensitization to protein antigens

270 It has been reported that LCs are dispensable for initiating contact hypersensitivity to

271 haptens, which may cast a discrepancy to our findings on the necessity of LCs to protein 272 antigen sensitization $(21,24)$. To evaluate the extent of skin penetration by protein 273 antigens and haptens, we patched fluorescein isothiocyanate (FITC)-conjugated OVA or 274 painted FITC on the back skin of B6 mice, and performed immunohistochemical 275 analysis. FITC-conjugated OVA retained above the TJ was indicated by staining with anti-claudin-1 antibody (Fig. S2, left panel). On the other hand, when we painted FITC on the skin of the mouse back skin, it readily penetrated into the dermis where dermal DCs locate (Fig. S2, right panel).

\section{LCs are critical for IgE production}

281 To further assess the role of LCs in IgE production, we used gene-targeted

282 Langerin-diphtheria toxin subunit A (DTA) mice (named Langerin-DTA mice), which 283 constitutively lack LCs throughout life (19). WT and Langerin-DTA mice were bred 284 under SPF conditions for six to ten weeks, and serum IgE levels were measured by 285 means of ELISA. On the FVB background, the serum IgE level was lower in 286 Langerin-DTA mice than in WT controls (Fig. 3A, left panel), while no significant 287 difference was seen on the C57BL/6 (B6) background (Fig. 3A, right panel). We also 288 found that the expression level of IgE on peritoneal mast cells was decreased in 289 LC-deficient mice in both the FVB and B6 backgrounds (Fig. 3B). Pre-incubation of 
mast cells with IgE in vitro did not change the data arguing that surface expression of

291 FceRI on mast cells was decreased in LC deficient mice, which is an indicator of lower

292 serum IgE. Therefore, the above data strongly suggest that LCs are crucial for IgE

293 production, which is consistent with the findings in the OVA-induced skin

294 inflammation model (Fig. 1, Fig. 2).

295

296 TSLP receptor on LCs is upregulated by protein antigen exposure

297 It has been reported that TSLP is involved in exacerbation of mouse Th2-mediated

298 allergic inflammation through direct stimulation of Th2 effector cells (25). However, it

299 remains unknown which cells initiate Th2 induction via TSLP signaling under

300 epicutaneous sensitization of protein antigens. TSLP is highly expressed in the skin

301 lesions of human $\operatorname{AD}(17,18,26,27)$, and the major cells in proximity to keratinocytes

302 are LCs; therefore, we evaluated the effect of TSLPR expression on LCs. We found that

303 LCs expressed TSLPR, but the expression level was low under the steady state. On the

304 other hand, the expression level of TSLPR on LCs was pronouncedly enhanced by

305 topical application of OVA (Fig. 4).

306

307 Establishment of BMC mice deficient in TSLPR on LC

308 Next we sought to clarify the significance of TSLP in epicutaneous sensitization with 309 protein antigens and to identify responsible cells mediating TSLP signaling. Since cells 310 ensuring epidermal LC renewal are radioresistant, LCs and their derivatives found in 311 skin-draining LNs are of host origin (28). We irradiated B6 mice and B6 background 312 TSLPR-deficient $\left(\mathrm{TSLPR}^{-/-}\right)$mice, and then transferred bone marrow cells from B6 313 mice into the irradiated mice. TSLPR is expressed on not only LCs, but also T cells, B 
314 cells, basophils, eosinophils, and dermal DCs. Of note LCs are radioresistant while T

315 cells, B cells, basophils, eosinophils, and dermal DCs are radiosensitive. When mice

316 were irradiated and transplanted with bone marrow cells, more than $95 \%$ of the blood

317 cells in the recipient mice had been replaced with donor-derived cells within two

318 months after the transfer, whereas almost $100 \%$ of LCs were derived from the host,

319 unlike the vast majority of dermal DCs that were donor-derived at this point (Fig. 5A).

320 Therefore, given that TSLPR ${ }^{-/}$mice were reconstituted with bone marrow cells from B6

321 mice, these mice were deficient in TSLPR on LCs, but other bone marrow-derived cells

322 expressing TSLPR were present. Accordingly, using a hematopoietic bone marrow

323 chimeric (BMC) system, we generated mice in which TSLPRs were lacking in LCs

324 (LC-TSLPR ${ }^{-/}$BMC mice) (Fig. S3).

325

326 Essential target of TSLP is TSLPR on LCs in OVA-induced allergic skin

327 dermatitis model

328 In the context of OVA-induced AD-like skin inflammation, LC-TSLPR ${ }^{-/-}$BMC mice

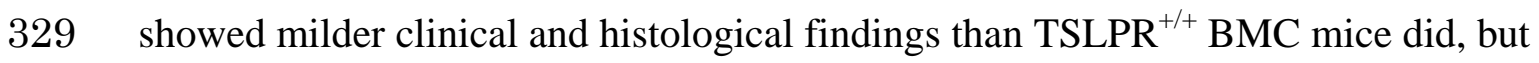

330 these findings were nearly comparable with those of TSLPR ${ }^{-/} \mathrm{BMC}$ mice (Fig. 5B, Fig.

331 S4). Consistently, OVA-specific IgE levels in the serum after OVA challenge were

332 significantly lower in LC-TSLPR ${ }^{-/-} \mathrm{BMC}$ mice than in $\mathrm{TSLPR}^{+/+} \mathrm{BMC}$ mice (Fig. 5C).

333 These data indicate LCs play an important role in epicutaneous sensitization upon

334 protein antigens in accord with IgE induction through TSLP-TSLPR signaling.

335

336 TSLPR on LCs are dispensable for antigen-specific $\mathbf{T}$ cell proliferation, but vital

337 for Th2 induction 
338 The above results suggest that LCs stimulate T cells to differentiate into Th2, resulting

339 in IgE induction. To clarify this issue, we assessed the T cell proliferation and

340 differentiation capacity of LCs in the presence or absence of TSLPR. We transferred

341 CFSE-labeled OT-II T cells into mice topically treated with OVA, and dividing cells in

342 the draining LNs were measured by means of flow cytometry (Fig. 6A). The ratio of

343 dividing OT-II CD4 ${ }^{+}$T cells to undivided OT-II CD4 ${ }^{+} \mathrm{T}$ cells was comparable among

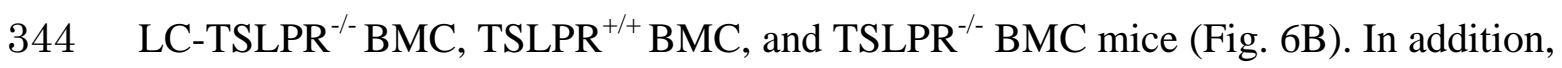

345 IFN- $\gamma$ mRNA level in the draining LNs 96 hours after OVA application was similar

346 among these three groups (Fig. 6C). On the other hand, the IL-4 mRNA expression

347 level in skin-draining LNs was significantly lower in LC-TSLPR ${ }^{-/-}$BMC mice than in

348 the other two groups (Fig. 6C). These results indicate that TSLPR on LCs are

349 dispensable for antigen-specific T cell proliferation but vital for inducing Th2

350 differentiation.

TSLP promotes expression of OX40L and production of Th2 chemokines by DCs

353 We next sought to elucidate the mechanism underlying Th2 induction of LCs via

354 TSLP-TSLPR signaling. Modulation of costimulatory molecule expression was among

355 the candidates, as it has been demonstrated that the interaction between membrane

356 OX40L on DCs and OX40 on naive T cells results in the induction of IL-4 production

357 by $\mathrm{T}$ cells in humans (26), and that treating mice with OX40L-blocking antibodies

358 substantially inhibited Th2 immune responses induced by TSLP in the lung and skin 359 (29).

360 Therefore, it is important to evaluate the expression levels of costimulatory molecules 361 on LCs in OVA-sensitized skin by means of flow cytometry. TSLPR ${ }^{-/-}$(BALB/c 
background) and WT control BALB/c mice were sensitized with OVA percutaneously.

Seventy-two hours later, epidermal cell suspensions were prepared and stained with anti-OX40L, CD80, and CD40 antibodies. The MFI of OX40L expressed by LCs from OVA-sensitized $\mathrm{TSLPR}^{-/-}$mice was significantly lower than that in WT control mice.

On the other hand, expression levels of CD40 and CD80 on LCs were comparable between WT control and TSLPR ${ }^{-/-}$mice (Fig. S5A).

It is known that serum levels of CCL17 and CCL22 correlate with the severity of AD

(5). We incubated bone marrow-derived DCs (BMDCs) from BALB/c mice with recombinant mouse TSLP, and found that TSLP induced DCs to express CCL17 and CCL22 mRNA (Fig. S5B), while the expression level of the Th1 chemokine CXCL10 was suppressed by TSLP (Fig. S5C). These results suggest that TSLP instructs cutaneous DCs to create a Th2-permissive microenvironment by modulating the expression levels of chemokines.

\section{DISCUSSION}

377 In this study, we have demonstrated that LCs are the essential cutaneous DC subset in 378 the induction of IgE upon epicutaneous sensitization with protein antigens. We also 379 found that TSLPR expression on LCs is enhanced upon protein antigen exposure to the 380 skin and that LCs plays an important role in this process through TSLP-TSLPR 381 signaling. In addition, we have demonstrated that TSLP stimulation causes LCs to express OX40L as shown previously in human studies, and that BMDCs induce Th2 chemokines while suppressing Th1 chemokines, which may shift the immune 384 environment to a Th2 milieu.

385 While a previous report suggests the significance of LCs in the induction of Th2 
immune responses in humans (30), other studies have reported that dermal DCs, but not

LCs, are essential for murine epicutaneous sensitization with hapten, as in contact hypersensitivity that is mediated by Th1 $(19,21,31,32)$. In our study, we have demonstrated that LCs seem to be indispensable for Th2 induction upon protein antigen sensitization. Therefore, dermal DCs and LCs may play an important role for Th1 and Th2 type immune reactions, respectively.

392 While protein antigens remain above the TJ, haptens can readily penetrate into the 393 dermis as shown in Fig. S2; therefore, LCs may not be essential for sensitization to 394 hapten as reported previously $(21,24)$. Upon protein antigen exposure to the skin, on 395 the other hand, LCs are vital in the induction of antigen-specific IgE. It is still an intriguing issue how clinical and histological scores, T cell proliferation, and IL-4 production were only partially suppressed by deficiency of LCs. These results suggest that other antigen presenting cells, such as dermal DCs, might be able to induce antigen-specific T cell proliferation in the draining LNs and that other Th2 inducing cells, such as basophils and mast cells, may contribute to produce IL-4 in the draining LNs. These issues need to be answered in the future.

402 It has been reported that basophils induce Th2 through TSLPR and that LCs are 403 essential in the vitamin D3 induced-skin lesions through TSLP signaling $(13,15)$. In this 404 study, we have demonstrated the significance of TSLP-TSLPR signaling on LCs under 405 epicutaneous sensitization with protein antigens, which is clinically relevant to AD. Our findings will lead to the understanding of underlying mechanism and developing new 407 therapeutic targets for inflammatory skin diseases.

\section{References}


410 1. Egawa G, Kabashima K. Skin as a Peripheral Lymphoid Organ: Revisiting the 411 Concept of Skin-Associated Lymphoid Tissues. J Invest Dermatol. 2011 Jul 7.

412 2. Moniaga CS, Kabashima K. Filaggrin in atopic dermatitis: flaky tail mice as a 413 novel model for developing drug targets in atopic dermatitis. Inflamm Allergy Drug 414 Targets. 2011 Nov 1.

$4153 . \quad$ Werfel T. The role of leukocytes, keratinocytes, and allergen-specific IgE in 416 the development of atopic dermatitis. J Invest Dermatol. 2009 Aug;129(8):1878-91.

4174 4. Nickel R, Beck LA, Stellato C, Schleimer RP. Chemokines and allergic disease. 418 J Allergy Clin Immunol. 1999 Oct;104(4 Pt 1):723-42.

419 5. Shimada Y, Takehara K, Sato S. Both Th2 and Th1 chemokines

420 (TARC/CCL17, MDC/CCL22, and Mig/CXCL9) are elevated in sera from patients with 421 atopic dermatitis. J Dermatol Sci. 2004 May;34(3):201-8.

$422 \quad 6 . \quad$ Banchereau J, Briere F, Caux C, Davoust J, Lebecque S, Liu YJ, et al.

423 Immunobiology of dendritic cells. Annu Rev Immunol. 2000;18:767-811.

4247 Novak N, Peng W, Yu C. Network of myeloid and plasmacytoid dendritic cells 425 in atopic dermatitis. Adv Exp Med Biol. 2007;601:97-104.

426 8. Poulin LF, Henri S, de Bovis B, Devilard E, Kissenpfennig A, Malissen B. The 427 dermis contains langerin+ dendritic cells that develop and function independently of 428 epidermal Langerhans cells. J Exp Med. 2007 Dec 24;204(13):3119-31.

429 9. Ginhoux F, Collin MP, Bogunovic M, Abel M, Leboeuf M, Helft J, et al.

430 Blood-derived dermal langerin+ dendritic cells survey the skin in the steady state. J Exp 431 Med. 2007 Dec 24;204(13):3133-46.

432 10. Bursch LS, Wang L, Igyarto B, Kissenpfennig A, Malissen B, Kaplan DH, et al. 433 Identification of a novel population of Langerin+ dendritic cells. J Exp Med. 2007 Dec 434 24;204(13):3147-56.

435 11. Kubo A, Nagao K, Yokouchi M, Sasaki H, Amagai M. External antigen uptake 436 by Langerhans cells with reorganization of epidermal tight junction barriers. J Exp Med. 4372009 Dec 21;206(13):2937-46.

438 12. Ziegler SF, Artis D. Sensing the outside world: TSLP regulates barrier 439 immunity. Nat Immunol. 2010 Apr;11(4):289-93.

440 13. Siracusa MC, Saenz SA, Hill DA, Kim BS, Headley MB, Doering TA, et al. 441 TSLP promotes interleukin-3-independent basophil haematopoiesis and type 2 442 inflammation. Nature. 2011 Aug 14.

443 14. Oyoshi MK, Larson RP, Ziegler SF, Geha RS. Mechanical injury polarizes skin 444 dendritic cells to elicit a $\mathrm{T}(\mathrm{H}) 2$ response by inducing cutaneous thymic stromal 445 lymphopoietin expression. J Allergy Clin Immunol. 2010 Nov;126(5):976-84, 84 e1-5. 
446 15. Elentner A, Finke D, Schmuth M, Chappaz S, Ebner S, Malissen B, et al.

447 Langerhans cells are critical in the development of atopic dermatitis-like inflammation

448 and symptoms in mice. J Cell Mol Med. 2009 Aug;13(8B):2658-72.

449 16. Ebner S, Nguyen VA, Forstner M, Wang YH, Wolfram D, Liu YJ, et al.

450 Thymic stromal lymphopoietin converts human epidermal Langerhans cells into

451 antigen-presenting cells that induce proallergic T cells. J Allergy Clin Immunol. 2007

452 Apr;119(4):982-90.

453 17. Soumelis V, Reche PA, Kanzler H, Yuan W, Edward G, Homey B, et al.

454 Human epithelial cells trigger dendritic cell mediated allergic inflammation by

455 producing TSLP. Nat Immunol. 2002 Jul;3(7):673-80.

456 18. Liu YJ. Thymic stromal lymphopoietin: master switch for allergic

457 inflammation. J Exp Med. 2006 Feb 20;203(2):269-73.

458 19. Kaplan DH, Jenison MC, Saeland S, Shlomchik WD, Shlomchik MJ.

459 Epidermal langerhans cell-deficient mice develop enhanced contact hypersensitivity.

460 Immunity. 2005 Dec;23(6):611-20.

461 20. Carpino N, Thierfelder WE, Chang MS, Saris C, Turner SJ, Ziegler SF, et al.

462 Absence of an essential role for thymic stromal lymphopoietin receptor in murine B-cell 463 development. Mol Cell Biol. 2004 Mar;24(6):2584-92.

464 21. Honda T, Nakajima S, Egawa G, Ogasawara K, Malissen B, Miyachi Y, et al. 465 Compensatory role of Langerhans cells and langerin-positive dermal dendritic cells in 466 the sensitization phase of murine contact hypersensitivity. J Allergy Clin Immunol. 4672010 May;125(5):1154-6 e2.

468 22. Spergel JM, Mizoguchi E, Brewer JP, Martin TR, Bhan AK, Geha RS.

469 Epicutaneous sensitization with protein antigen induces localized allergic dermatitis and 470 hyperresponsiveness to methacholine after single exposure to aerosolized antigen in 471 mice. J Clin Invest. 1998 Apr 15;101(8):1614-22.

472 23. Kissenpfennig A, Henri S, Dubois B, Laplace-Builhe C, Perrin P, Romani N, et 473 al. Dynamics and function of Langerhans cells in vivo: dermal dendritic cells colonize 474 lymph node areas distinct from slower migrating Langerhans cells. Immunity. 2005 475 May;22(5):643-54.

476 24. Kaplan DH. In vivo function of Langerhans cells and dermal dendritic cells. 477 Trends Immunol. 2010 Dec;31(12):446-51.

478 25. Kitajima M, Lee HC, Nakayama T, Ziegler SF. TSLP enhances the function of 479 helper type 2 cells. Eur J Immunol. 2011 Jul;41(7):1862-71. 
480 26. Ito T, Wang YH, Duramad O, Hori T, Delespesse GJ, Watanabe N, et al.

481 TSLP-activated dendritic cells induce an inflammatory $\mathrm{T}$ helper type 2 cell response 482 through OX40 ligand. J Exp Med. 2005 Nov 7;202(9):1213-23.

483 27. He R, Oyoshi MK, Garibyan L, Kumar L, Ziegler SF, Geha RS. TSLP acts on 484 infiltrating effector T cells to drive allergic skin inflammation. Proc Natl Acad Sci U S 485 A. 2008 Aug 19;105(33):11875-80.

486 28. Merad M, Manz MG, Karsunky H, Wagers A, Peters W, Charo I, et al.

487 Langerhans cells renew in the skin throughout life under steady-state conditions. Nat 488 Immunol. 2002 Dec;3(12):1135-41.

489 29. Seshasayee D, Lee WP, Zhou M, Shu J, Suto E, Zhang J, et al. In vivo 490 blockade of OX40 ligand inhibits thymic stromal lymphopoietin driven atopic 491 inflammation. J Clin Invest. 2007 Dec;117(12):3868-78.

492 30. Klechevsky E, Morita R, Liu M, Cao Y, Coquery S, Thompson-Snipes L, et al.

493 Functional specializations of human epidermal Langerhans cells and CD14+ dermal 494 dendritic cells. Immunity. 2008 Sep 19;29(3):497-510.

495 31. Kaplan DH, Kissenpfennig A, Clausen BE. Insights into Langerhans cell 496 function from Langerhans cell ablation models. Eur J Immunol. 2008 497 Sep;38(9):2369-76.

498 32. Mori T, Kabashima K, Yoshiki R, Sugita K, Shiraishi N, Onoue A, et al. 499 Cutaneous hypersensitivities to hapten are controlled by IFN-gamma-upregulated 500 keratinocyte Th1 chemokines and IFN-gamma-downregulated langerhans cell Th2 501 chemokines. J Invest Dermatol. 2008 Jul;128(7):1719-27.

502

503 
505

506

507

508

509

510

511

512

513

514

515

516

\section{FIGURE LEGENDS}

\section{FIG 1. LCs are crucial for epicutaneous sensitization with OVA.}

(A) Total clinical severity scores (left panel) and total histology scores (right panel) of LC-non-depleted (LC+) and LC-depleted (LC-) mice ( $\mathrm{n}=5$ mice per group). (B) Serum OVA-specific antibodies as determined by ELISA. Optical density value for IgE, IgG1, and IgG2a levels were measured at a wavelength of $450 \mathrm{~nm} .{ }^{*}, P<0.05$

\section{FIG 2. LCs are critical for antigen-specific $\mathbf{T}$ cell proliferation.}

Mice in the presence or absence of LCs (LC+ and LC-, respectively) were treated with OVA and transplanted with CFSE-labeled OT-II T cells ( $n=5$ mice per group).

Skin-draining LNs were analyzed for OVA-specific T cell proliferation (A and B) and mRNA expression levels for IFN- $\gamma$ and IL-4 (C). Boxes in (A) demarcate divided cells (left) and undivided cells (right) $*, P<0.05$. N.D., not detected.

\section{FIG 3. LCs are essential for IgE production.}

(A) The serum IgE levels and (B) IgE expression levels on peritoneal mast cells (indicated by MFI) of WT and Langerin-DTA mice on FVB (left panel) and B6 (right panel) backgrounds. Mast cells were also pre-incubated with IgE (labeled with pre IgE) in vitro before measurement of IgE expression (B). Each symbol represents an individual animal. ${ }^{*}, P<0.05$. sensitization. 
Epidermal cell suspensions from B6 (WT) mice with (sensitized) or without (non-sensitized) epidermal application of OVA were stained with TSLPR antibody. TSLPR expressions of MHC class $\mathrm{II}^{+} \mathrm{CD} 11 \mathrm{c}^{+} \mathrm{LCs}$ was analyzed by flow cytometry (left, histogram; right, average $\pm \mathrm{SD}$ of MFI). $\mathrm{n}=3$ per group. ${ }^{*}, P<0.05$

\section{FIG 5. An essential target of TSLP for IgE induction is TSLPR on LCs.}

534 (A) B6 (Ly45.2) mice were irradiated and transplanted with BM cells from B6 (Ly45.1)

535 mice. The epidermis and dermis of BMC mice separated, and single-cell suspensions 536 were stained and analyzed by flow cytometry.

537 (B) Total clinical severity scores (left panel) and histology scores (right panel) of

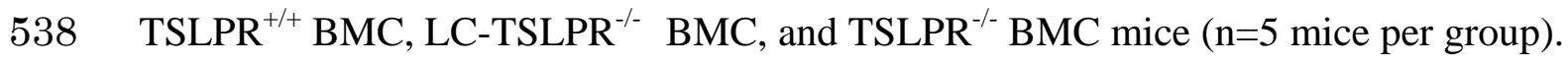
539 (C) Serum OVA-specific antibodies as determined by ELISA. Optical density value for $540 \mathrm{IgE}, \mathrm{IgG1}$, and IgG2a levels were measured at a wavelength of $450 \mathrm{~nm}$. *, $P<0.05$.

FIG 6. TSLPR on LCs are vital for Th2 induction

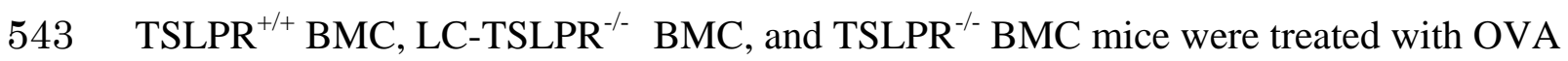
544 or saline and transplanted with CFSE-labeled OT-II T cells. Skin-draining LNs were 545 analyzed for OVA-specific T cell proliferation (A and B) and cytokine mRNA 546 expression levels for IFN- $\gamma$ and IL-4 (C). Boxes in (A) demarcate divided cells (left) 547 and undivided cells (right). $\mathrm{n}=5$ mice per group. $* P<0.05$. N.D., not detected. 
Figure 1

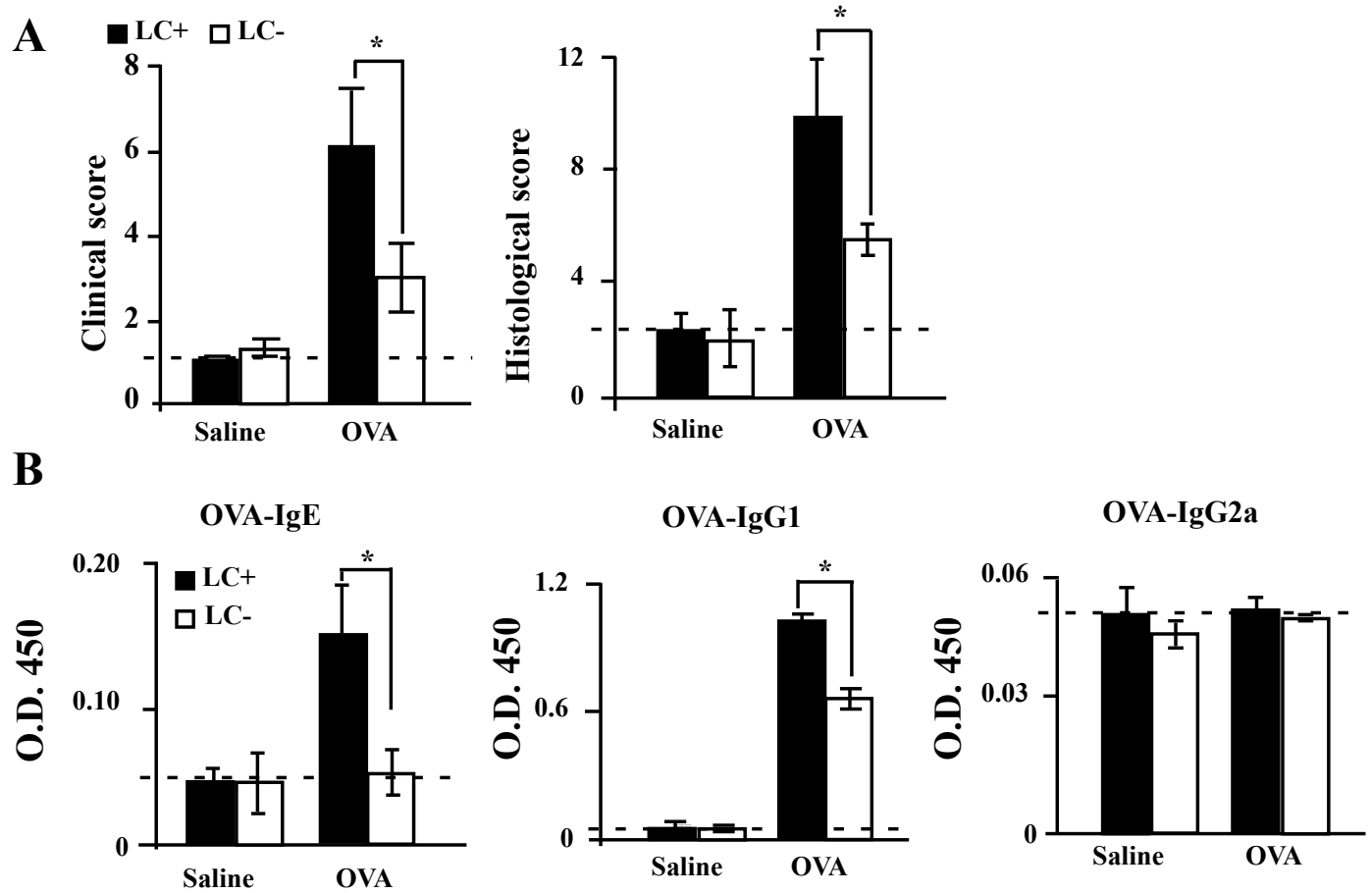


Figure 2
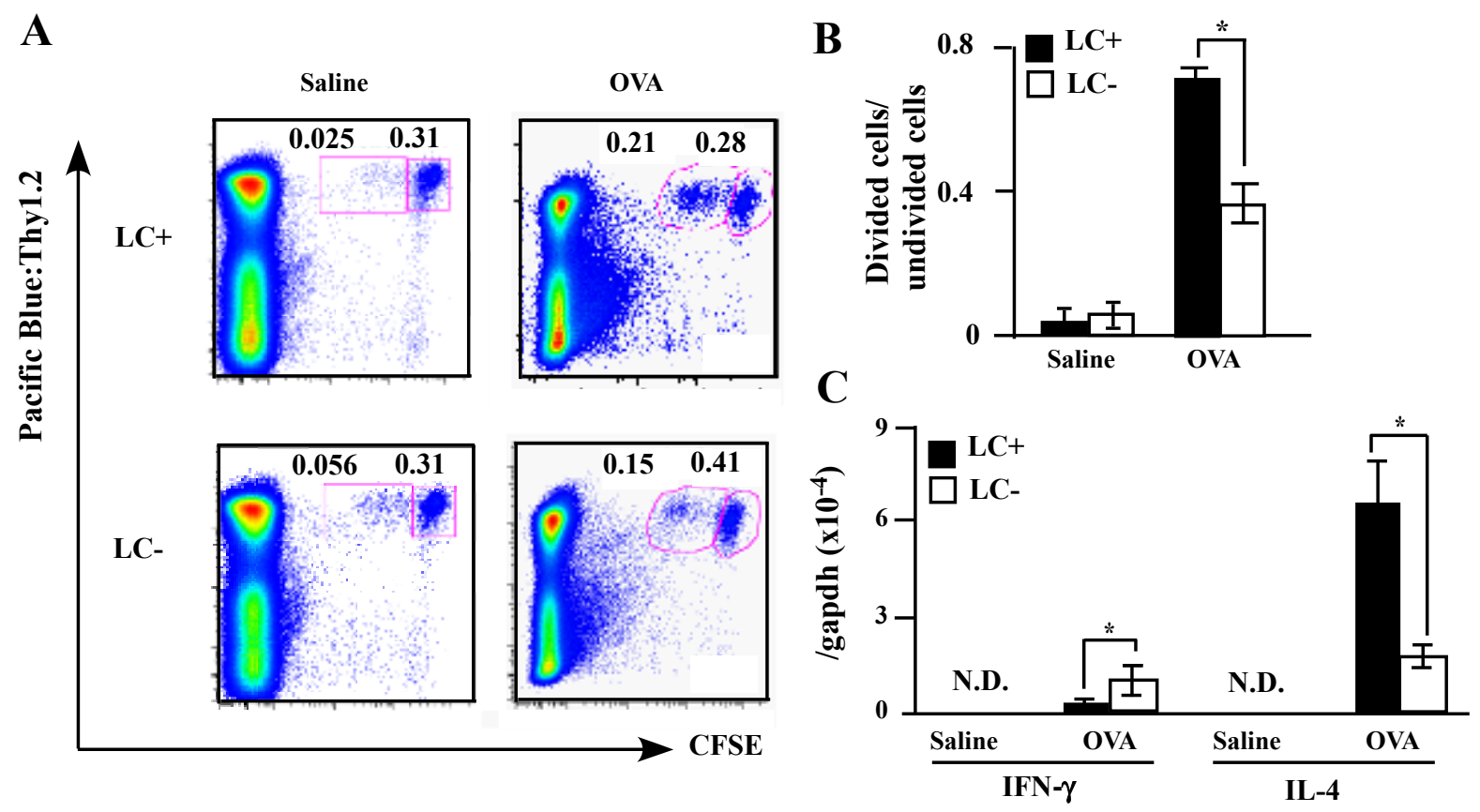
Figure 3

A
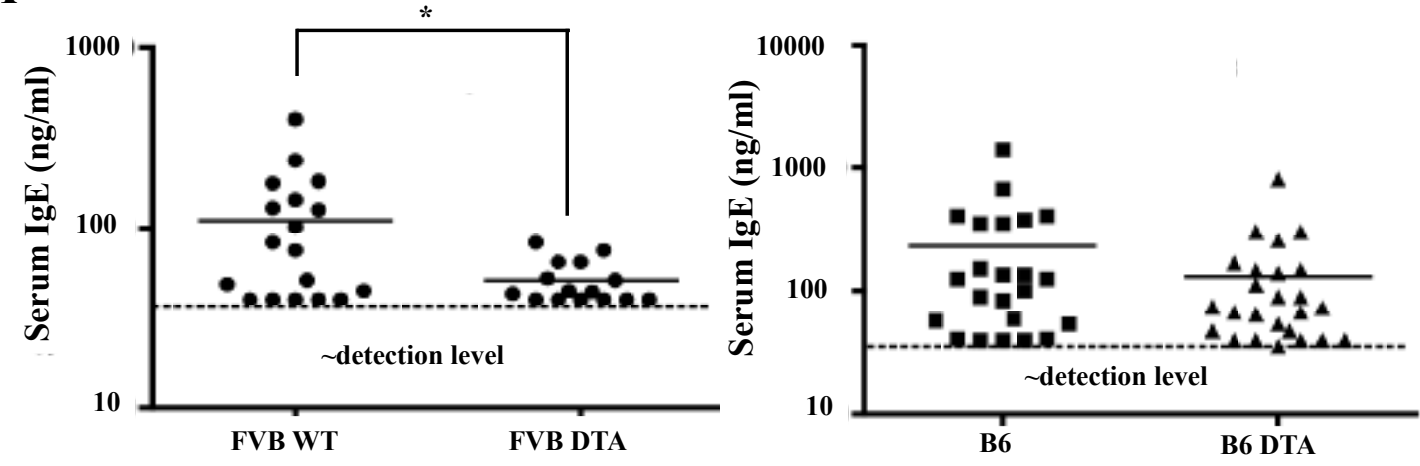

B
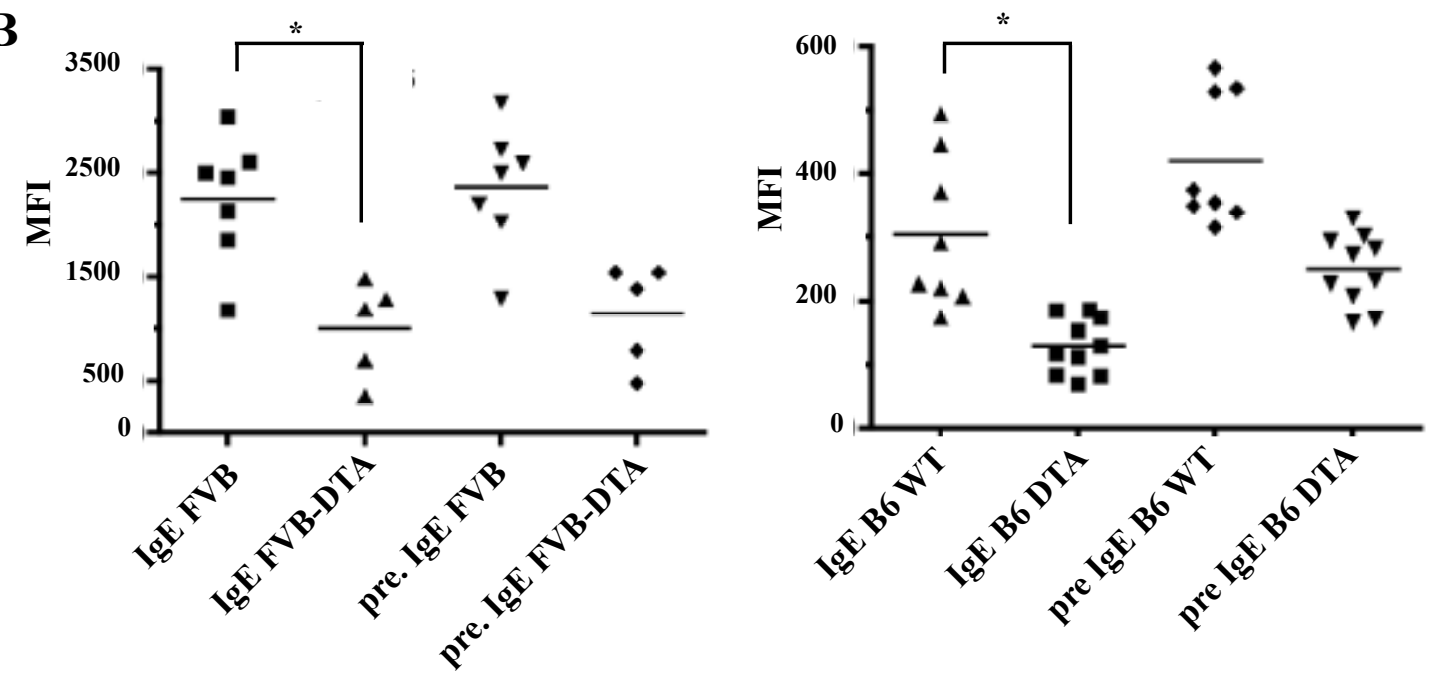


\section{Figure 4}
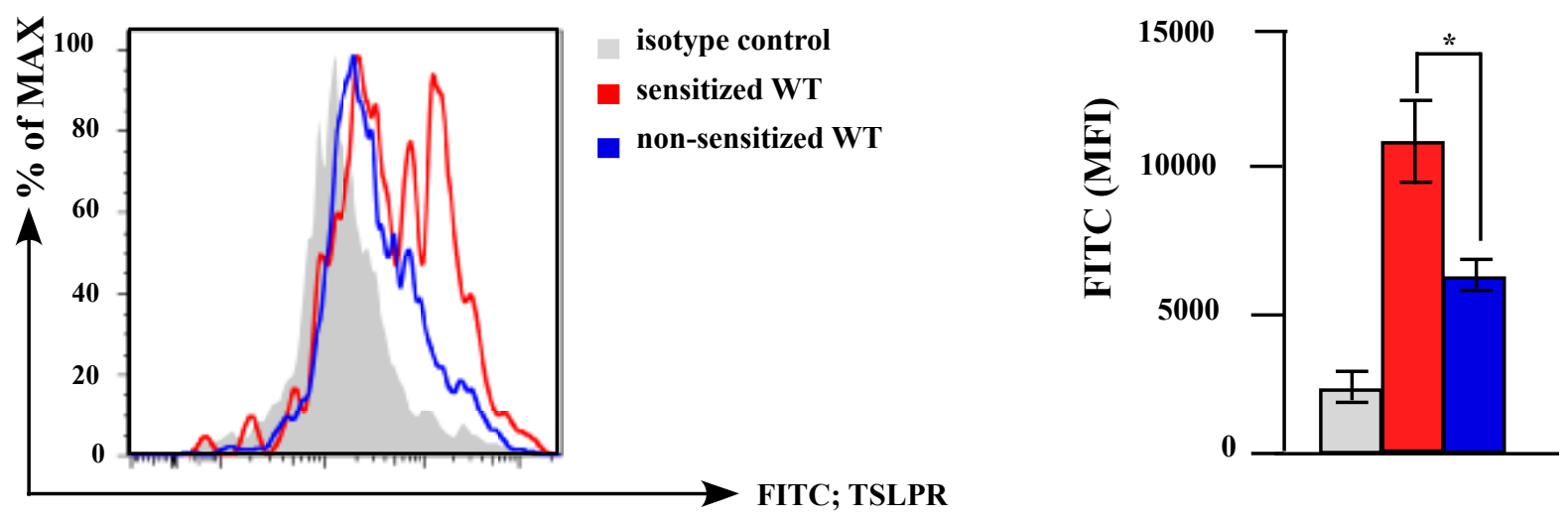


\section{Figure 5}

A
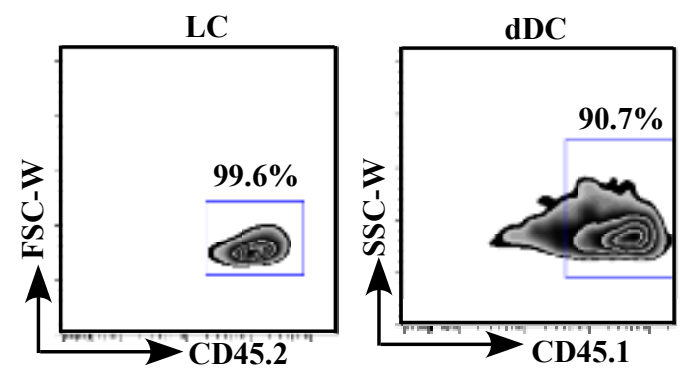

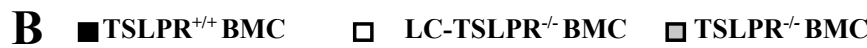
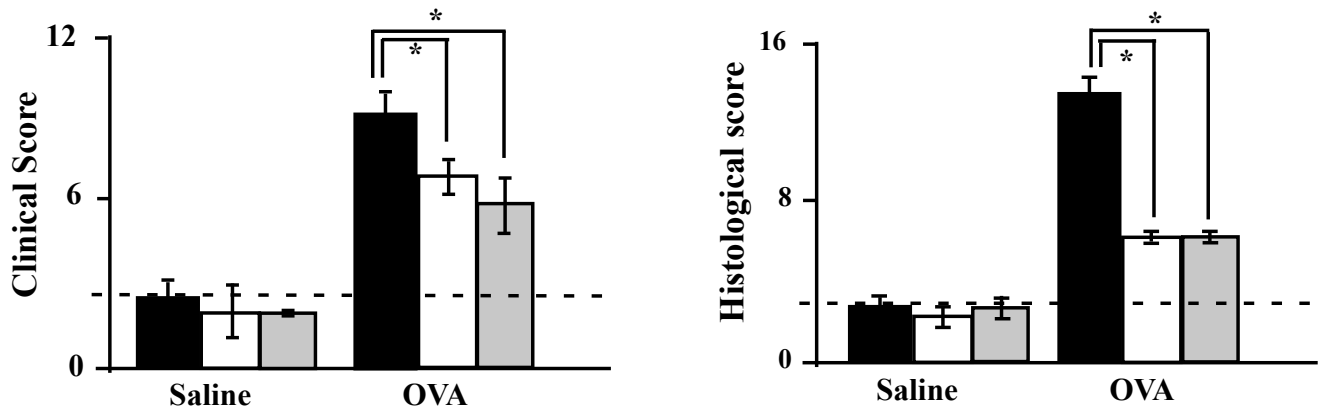

C

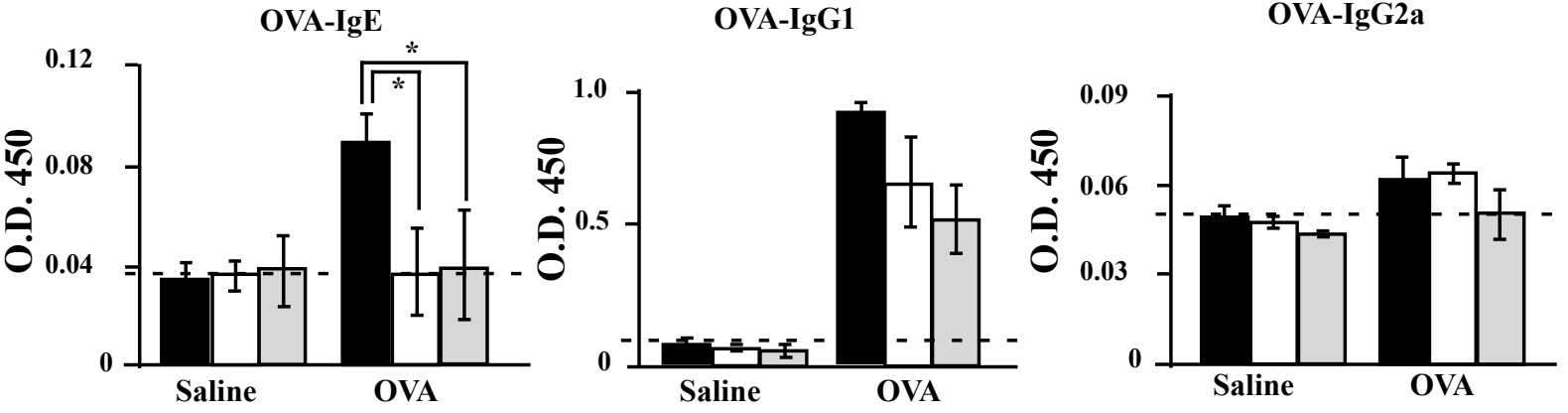




\section{Figure 6}

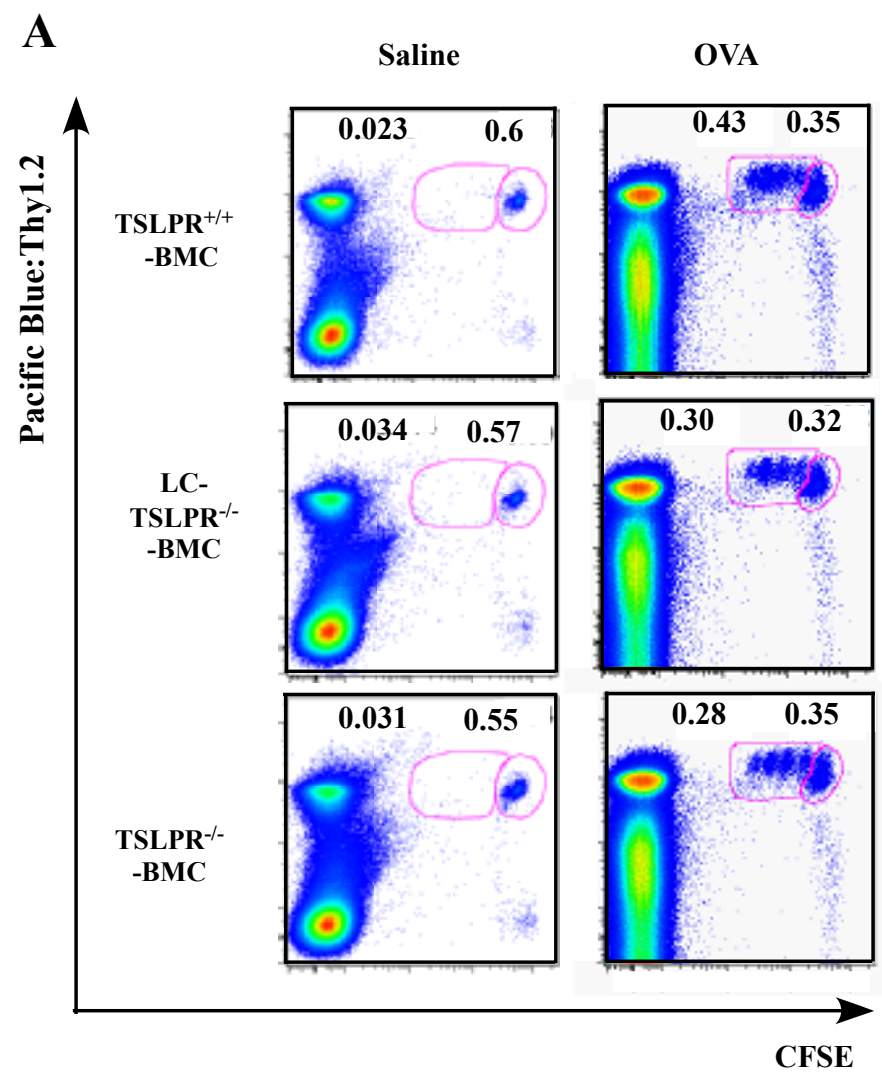

B $\square$ TSLPR $^{\text {+// }}$ BMC LC-TSLPR $^{-/}$BMC TSLPR $^{-/}$BMC $^{-}$
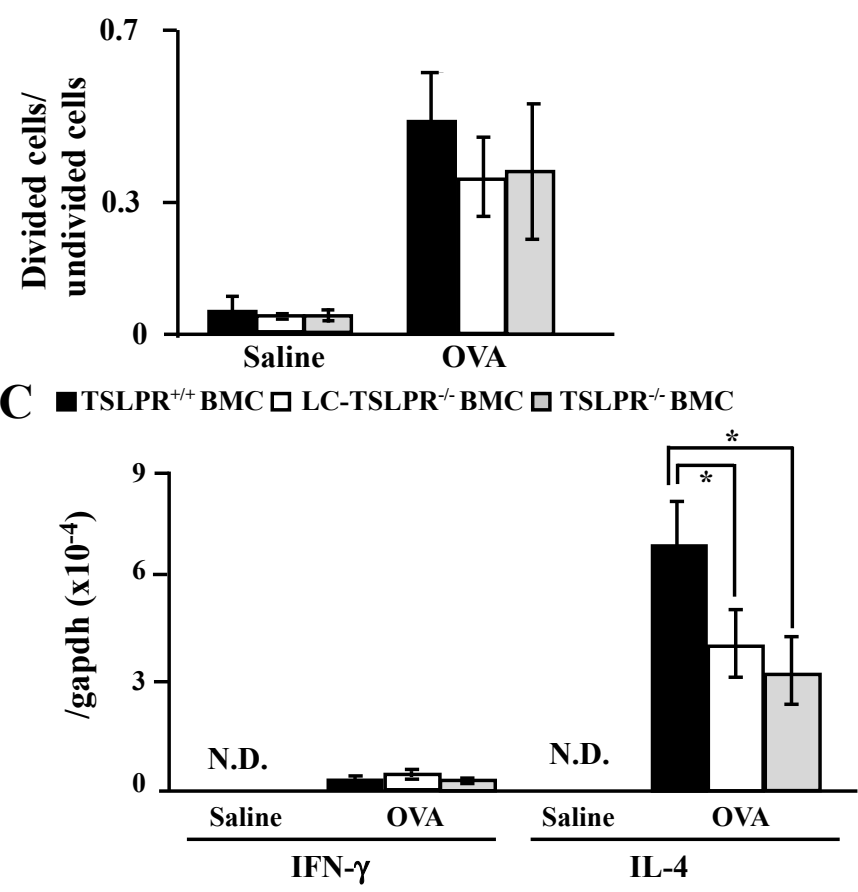


\section{Online Repository}

2

3 Langerhans cells are critical in epicutaneous sensitization with protein antigen via

$4 \quad$ TSLP receptor signaling

5

6 Saeko Nakajima, MD, Botond Igyarto, PhD, Tetsuya Honda, MD, PhD, Gyohei Egawa, $7 \mathrm{MD}, \mathrm{PhD}$, Atsushi Otsuka, MD, PhD, Mariko Hara-Chikuma, PhD, Norihiko Watanabe, 8 MD, PhD, Steven F Ziegler, PhD, Michio Tomura, PhD, Kayo Inaba, PhD, Yoshiki 9 Miyachi, $\mathrm{MD}, \mathrm{PhD}$, Daniel H Kaplan, MD, PhD, and Kenji Kabashima, MD, PhD

\section{SUPPLEMANTAL MATERIALS AND METHODS}

\section{Cell culture, reagents, antibodies, and flow cytometry}

14 The complete RPMI (cRPMI) culture medium consisting of RPMI 1640 (Invitrogen,

15 Carlsbad, CA, USA) containing $10 \%$ heat-inactivated fetal calf serum, $5 \times 10^{-5} \mathrm{M}$

16 2-mercaptoethanol, $2 \mathrm{mM}$ L-glutamine, $25 \mathrm{mM}$

17 N-2-hydroxyethylpiperazine-N'-2-ethanesulfonic acid, $1 \mathrm{mM}$ nonessential amino acids,

$181 \mathrm{mM}$ sodium pyruvate, 100 units $/ \mathrm{mL}$ penicillin, and $100 \mu \mathrm{g} / \mathrm{mL}$ streptomycin, was

19 used, unless otherwise indicated.

20 For bone marrow-derived DC (BMDC) culture, $5 \times 10^{6}$ BM cells generated from WT

21 and $\mathrm{TSLPR}^{-/-}$mice were cultured in $10 \mathrm{~mL}$ of cRPMI supplemented with $3 \mathrm{ng} / \mathrm{mL}$

22 recombinant murine granulocyte-macrophage colony-stimulating factor (PeproTech, 
23 Rocky Hill, NJ, USA) for 5 to 7 days. Then, 5 x $10^{5}$ cells were seeded in a 24-well

24 culture dish (Nunc, Rochester, NY, USA) in $500 \mu 1$ cRPMI and stimulated with 100

$25 \mathrm{ng} / \mathrm{ml}$ recombinant mouse TSLP (R\&D Systems, Minneapolis, MN, USA) for six hours.

26 For epidermal cell suspensions, dorsal skin sheets were floated on dispase II (GODO

27 SHUSEI CO., LTD, Aomori, Japan) diluted to $5 \mathrm{mg} / \mathrm{ml}$ in cRPMI for one hour at $37^{\circ} \mathrm{C}$

28 and $5 \% \mathrm{CO}_{2}$. The epidermis was separated from the dermis with forceps in RPMI

29 medium supplemented with $2 \%$ fetal calf serum. The isolated epidermis was cut finely

30 with scissors and floated in $0.25 \%$ trypsin-EDTA for $10 \mathrm{~min}$ at $37^{\circ} \mathrm{C}$ and $5 \% \mathrm{CO}_{2}$, and

31 filtered through a 40- $\mu$ m cell strainer (BD Bioscience, San Diego, CA, USA).

32 We purchased OVA from Sigma-Aldrich, and carboxyfluorescein succinimidyl ester

33 (CFSE) was acquired from Invitrogen. Fluorochrome-conjugated antibodies to CD4,

34 CD11c, CD90.1, MHC class II, OX40L, CD40, and CD80 were purchased from

35 eBioscience Inc. (San Diego, CA, USA). Anti-mouse TSLPR and isotype control were

36 purchased from R\&D systems. Cells were analyzed using the FACS LSR Fortessa flow

37 cytometric system (BD Bioscience) and FlowJo software (Tree Star, Ashland, OR, 38 USA).

39 
41 The clinical severity of skin lesions was scored according to the macroscopic diagnostic

42 criteria that were used for the NC/Nga mouse (4). In brief, the total clinical score for

43 skin lesions was designated as the sum of individual scores, graded as 0 (none), 1 (mild),

442 (moderate), and 3 (severe), for the symptoms of pruritus, erythema, edema, erosion,

45 and scaling. Pruritus was observed clinically for more than two minutes.

For histological examination, tissues were fixed with $10 \%$ formalin in phosphate buffer saline, and then embedded in paraffin. Sections with a thickness of $5 \mu \mathrm{m}$ were prepared and subjected to staining with hematoxylin and eosin. The histological findings were evaluated as reported previously (5).

For immunohistochemical analysis, OVA-sensitized skin samples were directly frozen at $-80^{\circ} \mathrm{C}$ in Tissue-Tek O.C.T. (Sakura Finetek, Tokyo, Japan). Skin cryosections were fixed with $4 \%$ paraformaldehyde (Nacalai Tesque) and permeabilized with $0.1 \%$

53 Triton-X (Sigma-Aldrich) in PBS for 10 minutes at room temperature. Next, slides were 54 incubated with anti-claudin-1 polyclonal antibody (Abcam, Cambridge, UK).

55 Immunodetection was performed using Alexa Fluor 594-coupled secondary antibody

56 (Invitrogen). The slides were mounted in ProLong Gold Antifade reagent (Invitrogen),

57 and fluorescence images were obtained using a BIOREVO BZ-9000 system (Keyence, 58 Osaka, Japan).

59 For assessing penetration of allergen, mice were percutaneously sensitized with 100 $60 \mu \mathrm{g}$ of fluorescein isothiocyanat (FITC)-conjugated OVA (Molecular Probes, Inc., 61 Eugene, OR, USA) diluted in $100 \mu 1$ normal saline onto the shaved and tape-stripped 
back skin. Seventy-two hours later, immunohistochemical analysis of the skin to assess allergen penetration was performed. Similarly, $100 \mu 1$ of $1 \%$ FITC (Sigma-Aldrich) in acetone/dibutyl phthalate (1/1) was applied to shaved dorsal skin of B6 mice; 72 hours later, immunohistochemical analysis was performed to assess hapten penetration into the skin.

\section{ELISA for OVA-specific serum IgE}

Total serum IgE levels were measured using a Bio-Rad (Hercules, CA, USA) Luminex

70 kit according to the manufacturer's instructions. To measure OVA-specific

$71 \mathrm{IgE} / \operatorname{IgG} 1 / \operatorname{IgG} 2 \mathrm{a}$ levels, the appropriate mouse IgE/IgG1/IgG2a ELISA kit (Bethyl

72 Laboratories, Montgomery, TX, USA) was used with slight modifications. Specifically,

73 plates were coated and incubated with $10 \mu \mathrm{g} / \mathrm{ml}$ OVA diluted with coating buffer for 2

74 hours. After a blocking period of 30 minutes, $100 \mu 1$ of $5 \mathrm{x}$ diluted serum was added

75 into each well and incubated for 2 hours. Anti-mouse IgE/IgG1/IgG2a-horseradish

76 peroxidase conjugate $(1: 15,000 ; 100 \mu \mathrm{L})$ was used to conjugate the antigen-antibody

77 complex for 60 minutes at room temperature; from this point on the ELISA kit was used 78 according to the manufacturer's instructions. Absorbance was measured at $450 \mathrm{~nm}$. The

79 difference between the sample absorbance and the mean of negative control absorbance 80 was taken as the result.

81 To measure IgE levels on peritoneal mast cells, the peritoneal cavity was rinsed with

$8210 \mathrm{ml}$ of ice-cold, sterile PBS. The collected cell suspension was incubated with 
83 Fc-block antibody (BD Biosciences; 2-4G2), washed and split in half. Half of the cells were kept untreated while the other half were incubated with $10 \mu \mathrm{g} / \mathrm{ml}$ of anti-DNP-IgE (mouse monoclonal IgE, Sigma-Aldrich) for 40 minutes on ice. After being washed with staining media, the cells were further incubated with an anti-c-kit and anti-mouse $\operatorname{IgE}$ and analyzed using a flow cytometer.

\section{Quantitative reverse-transcribed PCR analysis}

Total RNAs were isolated with RNeasy kits and digested with DNase I (Qiagen, Hilden, Germany). cDNA was reverse transcribed from total RNA samples using the Prime Script RT reagent kit (Takara Bio, Otsu, Japan). Quantitative RT-PCR was performed by monitoring the synthesis of double-stranded DNA during the various PCR cycles, using

94 SYBR Green I (Roche, Basel, Switzerland) and the Light Cycler real time PCR apparatus (Roche) according to the manufacturer's instructions. All primers were

96 obtained from Greiner Japan (Tokyo, Japan). The primer sequences were IFN- $\gamma, 5^{\prime}-$

97 GAA CTG GCA AAA GGA TGG TGA -3' (forward), 5' - TGT GGG TTG TTG ACC

98 TCA AAC -3' (reverse); IL-4, 5'- GGT CTC AAC CCC CAG CTA GT -3' (forward), 5'- GCC GAT GAT CTC TCT CAA GTG AT -3' (reverse); CCL17, 5'- CAG GGA TGC CAT CGT GTT TCT -3’ (forward), 5'- GGT CAC AGG CCG TTT TAT GTT -3’

101 (reverse); CCL22, 5' - TCT TGC TGT GGC AAT TCA GA -3' (forward), 5'- GAG GGT

103 TTC-3' (forward), 5'- GGC TCG CAG GGA TGA TTT CAA-3' (reverse). The cycling 
Nakajima et al

104 conditions were as follows: initial enzyme activation at $95^{\circ} \mathrm{C}$ for $10 \mathrm{~min}$, followed by

10540 cycles at $95^{\circ} \mathrm{C}$ for 10 seconds, and $60^{\circ} \mathrm{C}$ for 20 seconds. All cycling reactions were

106 performed in the presence of $3.5 \mathrm{mM} \mathrm{MgCl}_{2}$. Gene-specific fluorescence was measured

107 at $60^{\circ} \mathrm{C}$. For each sample, triplicate test reactions and a control reaction lacking reverse

108 transcriptase were analyzed for expression of the genes, and results were normalized to

109 those of the 'housekeeping' glyceraldehyde-3-phosphate dehydrogenase (GAPDH)

110 mRNA.

114 E1. Kaplan DH, Jenison MC, Saeland S, Shlomchik WD, Shlomchik MJ.

115 Epidermal langerhans cell-deficient mice develop enhanced contact hypersensitivity.

116 Immunity. 2005 Dec;23(6):611-20.

117 E2. Carpino N, Thierfelder WE, Chang MS, Saris C, Turner SJ, Ziegler SF, et al.

118 Absence of an essential role for thymic stromal lymphopoietin receptor in murine B-cell

119 development. Mol Cell Biol. 2004 Mar;24(6):2584-92.

120 E3. Honda T, Nakajima S, Egawa G, Ogasawara K, Malissen B, Miyachi Y, et al.

121 Compensatory role of Langerhans cells and langerin-positive dermal dendritic cells in

122 the sensitization phase of murine contact hypersensitivity. J Allergy Clin Immunol.

1232010 May;125(5):1154-6 e2.

124 E4. Leung DY, Hirsch RL, Schneider L, Moody C, Takaoka R, Li SH, et al.

125 Thymopentin therapy reduces the clinical severity of atopic dermatitis. J Allergy Clin

126 Immunol. 1990 May;85(5):927-33. 
127 E5. Nakajima S, Honda T, Sakata D, Egawa G, Tanizaki H, Otsuka A, et al.

128 Prostaglandin I2-IP signaling promotes Th1 differentiation in a mouse model of contact

129 hypersensitivity. J Immunol. 2010 May 15;184(10):5595-603.

\section{SUPPLEMENTAL FIGURE LEGENDS}

132 Figure S1. (A) H\&E staining of the back skin of LC-non-depleted or LC depleted mice

133 after OVA application for three times (H\&E, original magnification x400). Scale bar,

$134100 \mu \mathrm{m}$. (B) The histological findings were scored by infammation, neutrophil

135 infiltration, mononuclear cell infiltration, edema and epithelial hyperplasia. Data are

136 presented as means $\pm \mathrm{SD}(\mathrm{n}=5)$.

137 Figure S2. Impaired penetration of protein antigen into the dermis. B6 mice were

138 patched with FITC-conjugated OVA on the back skin; 72 hours later, patched skin area

139 was analyzed by immunohistochemistry. FITC-conjugated OVA (green) retained above

140 the TJ was indicated by staining with anti-claudin-1 antibody (red) (left panel). FITC

141 (green) readily penetrated into the dermis (right panel). Blue staining (DAPI) indicates

142 nuclei. Dashed white lines represent the border between dermis and epidermis. Scale

143 bars, $100 \mu \mathrm{m}$.

144 Figure S3. Establishment of bone marrow chimeric mice deficient in TSLPR on

145 LC (LC-TSLPR ${ }^{-/}$BMC). B6 mice and B6-background TSLPR ${ }^{-/-}$mice were irradiated

146 (IR) and transplanted with BM cells (BMT) from B6 mice or TSLPR ${ }^{-/-}$mice. Since LCs

147 were radioresistant, when $\mathrm{TSLPR}^{-/-}$mice were reconstituted with BM cells from B6

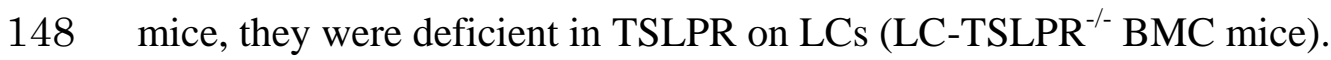

149 Figure S4. (A) H\&E staining of the back skin of TSLPR ${ }^{+/+}$, LC-TSLPR $^{-/}$, and TSLPR ${ }^{-/}$

150 mice after OVA application for three times (H\&E, original magnication $\mathrm{x} 400)$.Scale bar,

$151100 \mu \mathrm{m}$. (B)The histological findings were scored by infammation, neutrophil

152 infiltration, mononuclear cell infiltration, edema and epithelial hyperplasia. Data are

153 presented as means $\pm \mathrm{SD}(\mathrm{n}=5)$. 


\section{Figure S5. TSLP promotes expression of OX40L and production of Th2}

155 chemokines by DCs. (A) The expression levels of OX40L, CD80 and CD40 of LCs

156 with (sen+) or without (sen-) OVA sensitization in $\mathrm{TSLPR}^{+/+}$and $\mathrm{TSLPR}^{-/-}$mice $(\mathrm{n}=5$

157 mice per group). Cells were pregated on $\mathrm{MHC}$ class $\mathrm{II}^{+} \mathrm{CD} 11 \mathrm{c}^{+} \mathrm{LC}$ cells. (B, C)

158 BMDCs were incubated with or without recombinant TSLP (rTSLP), and mRNA levels

159 of chemokines, CCL17, CCL22, and CXCL10, were measured by real-time qPCR. *P $160<0.05$. 


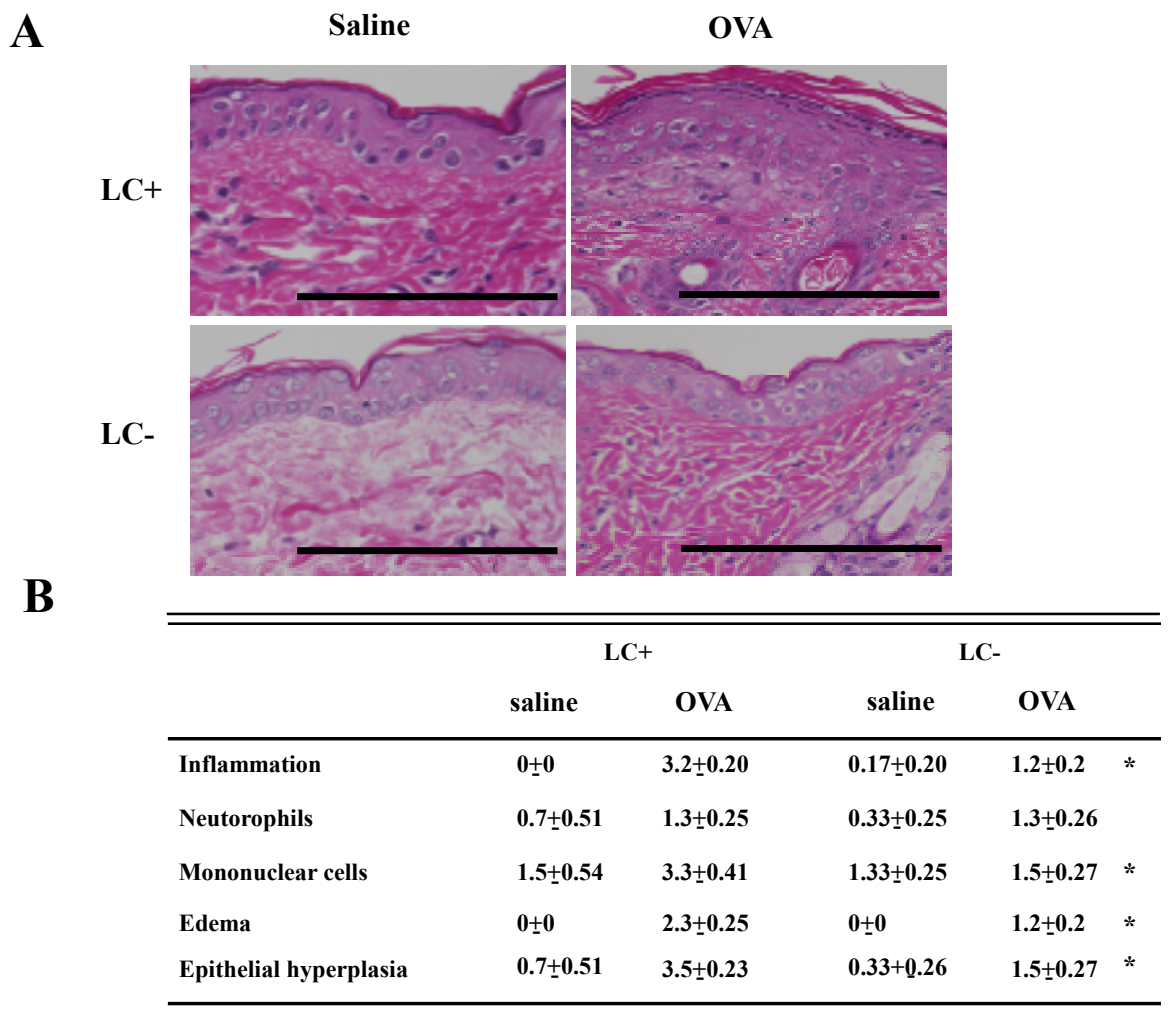

Figure S1. (A) H\&E staining of the back skin of LC-non-depleted or LC depleted mice after OVA application for three times (H\&E, original magnication x400). Scale bar, $100 \mu \mathrm{m}$. (B)The histological findings were scored by infammation, neutrophil infiltration, mononuclear cell infiltration, edema and epithelial hyperplasia. Data are presented as means $\pm \mathrm{SD}(\mathrm{n}=5)$ 

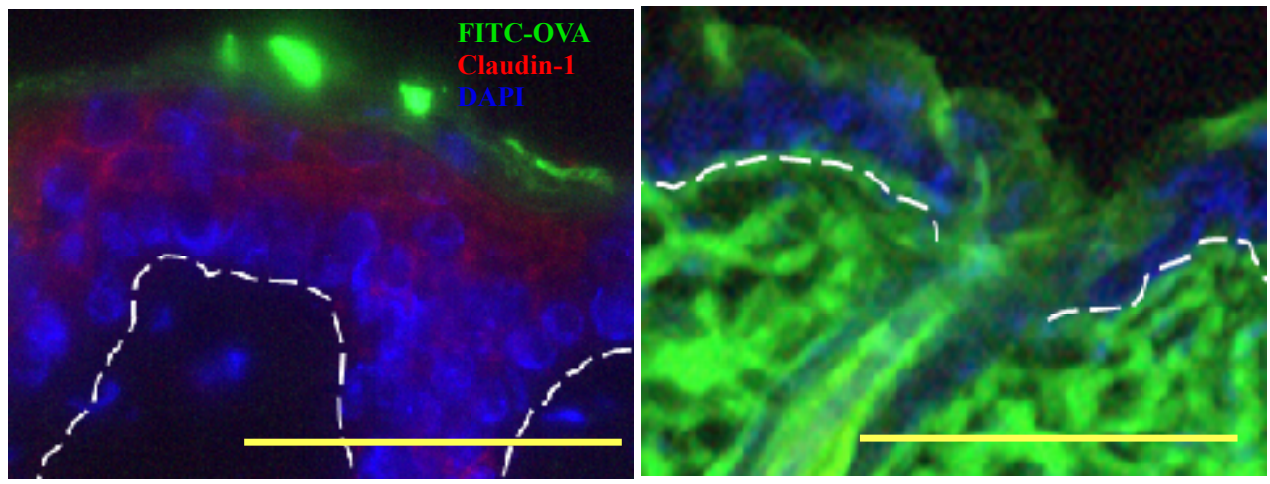

Figure S2. Impaired penetration of protein antigen into the dermis.

B6 mice were patched with FITC-conjugated OVA on the back skin; 72 hours later, patched skin area was analyzed by immunohistochemistry.

FITC-conjugated OVA (green) retained above the TJ was indicated by staining with anti-claudin-1 antibody (red) (left panel). FITC (green) readily penetrated into the dermis (right panel). Blue staining (DAPI) indicates nuclei. Dashed white lines represent the border between dermis and epidermis. Scale bars, $100 \mu \mathrm{m}$. 


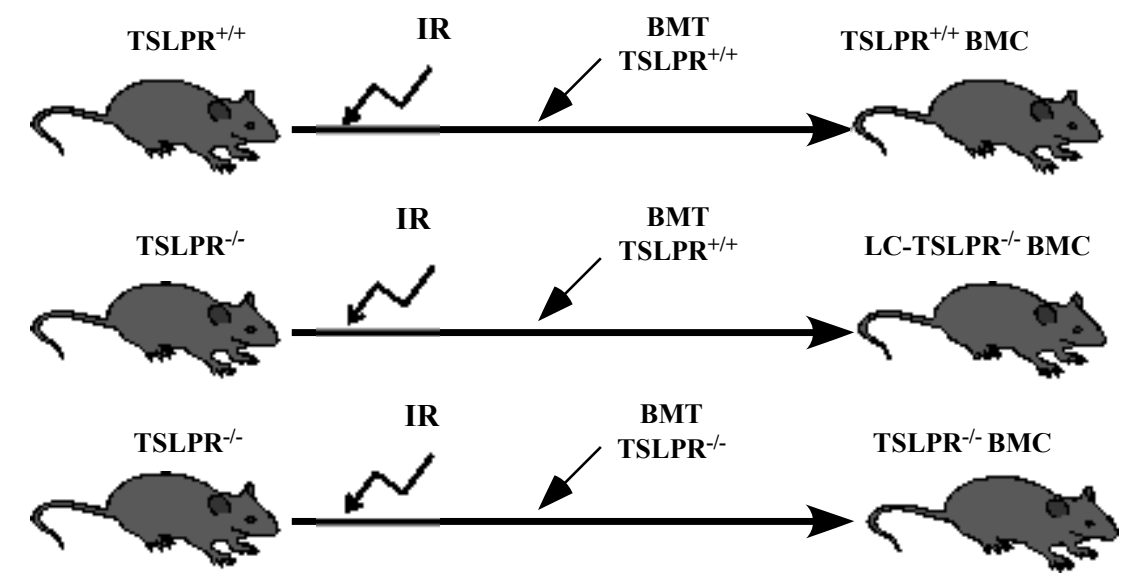

Figure S3. Establishment of bone marrow chimeric mice deficient in TSLPR on LC (LC-TSLPR ${ }^{-/-}$BMC).

B6 mice and B6-background TSLPR ${ }^{-/-}$mice were irradiated (IR) and transplanted with BM cells (BMT) from B6 mice or TSLPR ${ }^{-/-}$mice. Since LCs were radioresistant, when $\mathrm{TSLPR}^{-/}$mice were reconstituted with BM cells from B6 mice, they were deficient in TSLPR on LCs (LC-TSLPR ${ }^{-/}$BMC mice). 
A

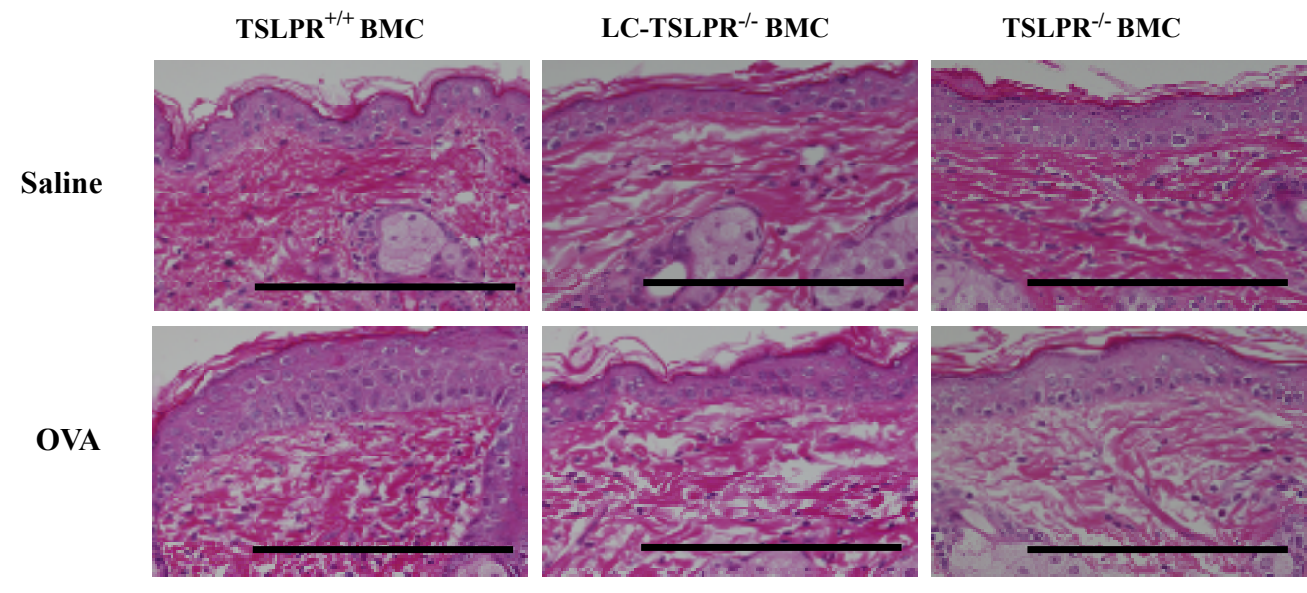

B

\begin{tabular}{llclclcc}
\hline \hline & \multicolumn{2}{c}{ TSLPR $^{+/+}$BMC } & \multicolumn{2}{c}{ LC-TSLPR $^{-/-} \mathrm{BMC}^{2}$} & \multicolumn{2}{c}{ TSLPR $^{-/-} \mathrm{BMC}^{2}$} \\
& saline & OVA & saline & OVA & saline & OVA \\
\hline Inflammation & $0 \pm 0$ & $3.2 \pm 0.2$ & $0.4 \pm 0.24$ & $1.2 \pm 0.2$ & $*$ & $0.4 \pm 0.24$ & $1.4 \pm 0.24$ \\
Neutorophils & $0.8 \pm 0.2$ & $1.8 \pm 0.37$ & $0.4 \pm 0.24$ & $1.2 \pm 0.2$ & $*$ & $0.6 \pm 0.24$ & $1.4 \pm 0.24$ \\
Mononuclear cells & $1.6 \pm 0.24$ & $3.2 \pm 0.37$ & $1.2 \pm 0.2$ & $1.6 \pm 0.24$ & $*$ & $1.0 \pm 0.32$ & $1.2 \pm 0.2$ \\
Edema & $0.2 \pm 0.2$ & $2.4 \pm 0.24$ & $0 \pm 0$ & $1.4 \pm 0.24$ & $*$ & $0.2 \pm 0.2$ & $1.4 \pm 0.24$ \\
Epithelial hyperplasia & $0.8 \pm 0.2$ & $3.6 \pm 0.24$ & $0.4 \pm 0.24$ & $1.2 \pm 0.2$ & $*$ & $0.6 \pm 0.24$ & $1.2 \pm 0.24$ \\
\hline
\end{tabular}

Figure S4. (A) H\&E staining of the back skin of TSLPR ${ }^{+/+}$, LC-TSLPR ${ }^{-/}$, and $\mathrm{TSLPR}^{-/-}$mice after OVA application for three times (H\&E, original magnication $\left.\mathrm{x} 400\right)$. Scale bar, $100 \mu \mathrm{m}$.

(B)The histological findings were scored by infammation, neutrophil infiltration, mononuclear cell infiltration, edema and epithelial hyperplasia. Data are presented as means \pm SD $(n=5)$ 


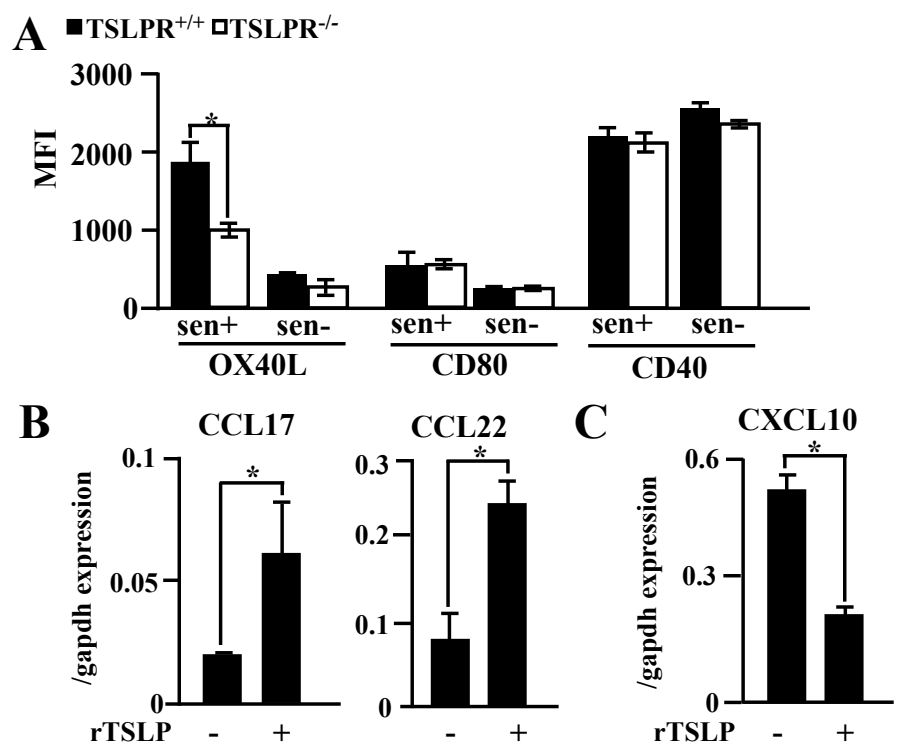

Figure S5. TSLP promotes expression of OX40L and production of Th2 chemokines by DCs.

(A) The expression levels of OX40L, CD80 and CD40 of LCs with (sen+) or without (sen-) OVA sensitization in TSLPR+/+ and TSLPR-/- mice

$(\mathrm{n}=5$ mice per group). Cells were pregated on MHC class II + CD11c + LC cells. $(\mathrm{B}, \mathrm{C})$ BMDCs were incubated with or without recombinant TSLP (rTSLP), and mRNA levels of chemokines, CCL17, CCL22, and CXCL10, were measured by real-time qPCR. ${ }^{*} \mathrm{P}<0.05$. 